\title{
Bornologiese pseudotopologiese vektorruimtes
}

\author{
M. A. Muller \\ Departement Wiskunde. Universitcit van Stellenbosch. Stellenbosch 7600
}

Omarang 10 April 1989: antmaar 4 Desember 1989

\section{('TTTREKSEL.}

Bornologiese rumbes is deur Hoghe-Nlends gedefinicer en pseudolopologiese ruimtes deur Fischer. ${ }^{3}$. In hierdie artikel word cienskappe van bornologiese pseudotopologiese veklorrumbes ondersock. "n Karakterisering van sulke ruimtes word

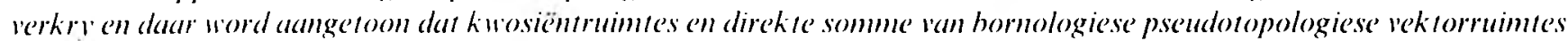

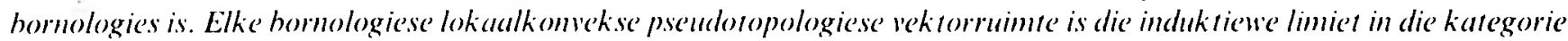

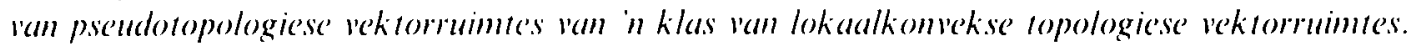

\section{ARSTRACT}

Bornological psendo-topological recror spaces

Bornological spaces were defined by Hoghe-Nlend in 1971 and psedudo-topological spaces hy Fischer in 1959. In this paper propertices of bornological psedudo-lopological vector spaces are investigated. A characterization of such spaces is obtained and it is shown that quoticht spaces and direct sums of hormological pseado-topological vector spaces are hornological. Every bornological locally comex pseado-topological vector space is shown to be the indactive limit in the category of pseudo-topological vector spaces of a family of locally convex ropological vector spaces.

\section{INI.EIDING EN NOTASIE}

Gestel $X$ en $Y$ is versamelings. As $A$ in nic-leë deelversameling van $X$ is, laat $[A]$ die filter in $X$ aandui wat deur: A ? voortgebring word; as $x \in X$ laat $[x]$ dic filter in $X$ aandui wat deur $\{\{x\}\}$ voortgebring word. Laat $\mathbb{I}(X)$ die versameling van alle filters in $X$ aandui. $A s$ $\mathfrak{f} \in \mathbb{E}(X)$, laat $[\mathfrak{f}]=\{\mathfrak{f} \in \mathbb{F}(X): \mathfrak{B} \supset \mathfrak{f}:$. As $H$ 'n nie-leë versameling van afbecldings van $X$ in $Y$ is, skryf ons $H(A)=\{h(a): h \in H . a \in A\}$. As $b$ ' $n$ filter in dic versameling van alle afbeeldings van $X$ in $Y$ is en $\mathfrak{f} \in \mathbb{F}(X)$, laat $\mathfrak{h}(\mathfrak{f})$ die filter in $Y^{\prime}$ wees wat deur $\{H(F): H \in \mathfrak{b}, F \in \mathfrak{f}\}$ voortgebring word. Indien daar vir elke $x \in \mathrm{X}$ in ooreenkomstige declversameling $\tau x$ van $\mathbb{Q}(\mathrm{X})$ bestaan wat die volgende eienskappe het:

(1) as $\mathbb{f} \in \tau x, \mathcal{B} \in \mathbb{V}(X)$ en $\mathbb{f} \subset \mathcal{B}$ dan $\mathcal{B} \in \tau x$,

(2) as $\mathbb{f} \in \tau x$ en $\mathfrak{B} \in \tau x$ dan $\mathbb{f} \cap \mathbb{B} \in \tau x$, en

(3) $[x] \in \tau x$,

dan word die paar $(X, \tau)$ 'n pseudotopologiese ruimte genoem. As $\mathfrak{f} \in \tau x$ sê ons die filter $\mathfrak{f}$ konvergeer na $x$. As $(X, \tau)$ en $(Y, \sigma)$ pseudotopologiese ruimtes is noem ons die afbeelding $f: \mathrm{X} \rightarrow \mathrm{Y}$ in die punt $x \in \mathrm{X}$ kontinu (meer presies: $\tau-\sigma$-kontinu) as vir $\mathbb{f} \in \tau x$ volg dat $f(\mathfrak{f}) \in \sigma f(x)$, waar $f(\mathfrak{f})$ dic filter in $\mathrm{Y}$ is wat deur $f(\mathrm{~F})$ : $\mathrm{F} \in \mathfrak{f}^{\prime}$ voortgebring word. Verder noem ons $f$ $\tau$ - $\sigma$-kontinu as $f$ in elke punt van $X \tau$ - $\sigma$-kontinu is.

In hierdie artikel word alle vektorruimtes oor die liggaam $\Phi$ van reële of komplekse getalle gedefinieer. Gestel $R$ is die versameling van reële getalle. As $E$ in vektorruimte is, $x \in \mathrm{E}, \mathrm{A} \subset \mathrm{E}, \mathrm{A} \neq \emptyset, x \in \Phi$, $\mathfrak{f} \in \mathbb{F}(\mathrm{E}), \mathbb{E} \in \mathbb{F}(\mathrm{E})$ en $\boldsymbol{h} \in \mathbb{F}(\Phi)$ dan is $x+\mathfrak{f}, \alpha \mathfrak{f}$, $\mathfrak{f}+\mathfrak{B}, \mathfrak{h}, \boldsymbol{h A}$ en $\mathbf{l} f$ filters in $\mathrm{E}$ wat onderskeidelik deur $\{x+F: F \in \mathbb{J}\},\{\alpha F: F \in \mathbb{f}\},\{F+G: F \in \mathbb{f}$, $G \in \mathfrak{B}\},\{H x: H \in \mathfrak{l}\},\{H A: H \in \mathfrak{l}\}$ en $\{H F: H \in \mathfrak{h}$, $F \in \mathbb{f}\}$ voortgebring word. Laat $\mathrm{N}_{\varepsilon}(0)=\{\lambda \in \Phi$ : $|\hat{i}| \leq \varepsilon_{i}^{\prime}$ en laat $\mathbf{2}(0)$ die filter in $\Phi$ wees wat deur $\left\{N_{\varepsilon}(0): \varepsilon>0\right.$; voortgebring word. As $E$ 'n vektor- ruimte is en $(E, \tau)$ is 'n pseudotopologiese ruimte sodat die albeeldings $(\mathrm{x}, \mathrm{y}) \rightarrow x+y$ van $\mathrm{E} \times \mathrm{E}$ in $\mathrm{E}$ en $(\alpha, x) \rightarrow \alpha x$ van $\Phi) \times E$ in $E$ beide kontinu is dan word (E. $\tau$ ) 'n pseudotopologiese vektorruimte genoem. Laat $\tau_{q p}$, waar $\tau_{\phi}(0=[\$ 2(0)]$, die pseudotopologiese vektorruimtestruktuur op $\Phi$ wees wat mel die natuurlike topologie op $\Phi$ geassosieer is. De Bruyn ${ }^{2}$ en Gählert gee die volgende definisies:

DEFINISIE 1. Gestel (E, $\tau$ ) is 'n pseudotopologiese rektorruimte.

(1) (E, $\tau$ ) is lokalhegrens as elke ff $\in \tau 0$ in $\tau$-begrensde

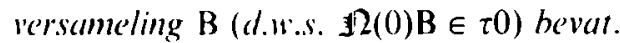

(2) (E. $\tau$ ) is ewewiglig as vir elke $\mathfrak{f} \in \tau 0$ daur 'n ooreenkomstige ewewigtige filter of (d.w.s.

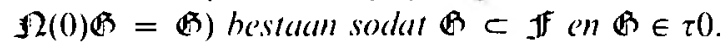

(3) (E, $\tau$ ) is bornologies as vir elke $1 f \in \tau 0$ daar 'n oorcenkomstige $\tau$-hegrensde versameling $\mathrm{B}$ bestam so-

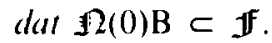

(4) $(\mathrm{E}, \tau)$ is lokaalkonveks as vir elke $\mathfrak{f} \in \tau 0$ daar 'n filter of bestaan wat 'n filterhasis van konvekse versamelings het sodat $\mathbb{B} \subset \mathbb{f}$ en $B \in \tau 0$.

(5) (E, $\tau$ ) is absorberend as vir elke $\mathfrak{f} \in \tau 0$ daar 'n absorberende filter (d.w.s. elke element van of is ' $n$ ahsorberende versameling) bestan sodat of $\subset \mathcal{I f}_{\mathrm{en}}$ of $\in \tau 0$.

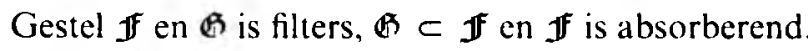
Dan is absorberend. Die pseudotopologiese vektorruimte $(\mathrm{E}, \tau)$ is absorberend as en slegs as $\tau 0$ 'n absorberende filter bevat.

DEFINISIE 2. Gestel (E, $\tau$ ) en $(\mathrm{F}, \sigma)$ is pseudotopologiese vektorruimtes on $f: \mathrm{E} \rightarrow \mathrm{F}$ is 'n afbeelding.

(1) $f$ is $\tau$ - $\sigma$-hegrens as vir elke $\tau$-hegrensde deelversameling $\mathrm{B}$ van $\mathrm{E}$ volg dat $f(\mathrm{~B})$ ' $n \sigma$-begrensde deelversameling van $\mathrm{F}$ is. 
(2) $f$ is $\tau-\sigma$-kwasibegrens as vir elke $\tau$-kwasibegrensde filter $\mathfrak{I}$ in $\mathrm{E}($ d.w.s. $\mathfrak{Z}(0) \mathfrak{f} \in \tau 0)$ volg dat $f(\mathbb{f})$ ' $n \sigma$ $k$ wasibegrensde filter in $F$ is.

(3) $f$ is $\tau-\sigma$-byna kontinu as vir elke $\mathrm{V} \in \cap\{(\mathbb{R}: \mathbb{B} \in \sigma 0\}$ volg $f^{-1}(\mathbf{V}) \in \cap\{\mathfrak{f}: \mathfrak{f} \in \tau 0\}$.

\section{KARAKTERISERING VAN BORNOLOGIESE PSEUDOTOPOLOGIESE VEKTORRUIMTES}

Gestel $(E, \tau)$ en $(F, \sigma)$ is pseudotopologiese vektorruimtes, $f: \mathrm{E} \rightarrow \mathrm{F}$ is 'n lineêre afbeelding en $\tau_{b} 0=\{\mathfrak{f} \in \mathbb{F}(E): \mathfrak{J} \supset \mathfrak{M}(0) B$ vir'n sekere $\tau$-begrensde versameling $B\}$. Dan is $\left(E, \tau_{b}\right)$ 'n pseudotopologiese ruimte. ${ }^{2}$ Verder is $f \tau$ - $\sigma$-begrens as en slegs as $f \tau_{h}-\sigma$ kontinu is.

HULPSTELLING 1. Gestel $(\mathrm{E}, \tau)$ en $(\mathrm{F}, \sigma)$ is pseudotopologiese vektorruimtes en $f: \mathrm{E} \rightarrow \mathrm{F}$ is 'n lineêre afbeelding. Gestel $(\mathrm{E}, \tau)$ is ewewigtig en vir elke $\mathfrak{f} \in \tau 0$ bestaan $\mathrm{U} \in \mathfrak{1}$ sodat $f(\mathrm{U}) \sigma$-begrens is. Dan is $f \tau-\sigma$ kontinu.

Bewys. Gestel $\in \tau 0$. Daar bestaan $\mathfrak{h} \in \tau 0$ sodat $\mathfrak{H}(0) \mathbf{h} \subset$ en daar bestaan $\mathbf{M} \in \mathcal{A}(0) \mathbf{b}$ so-

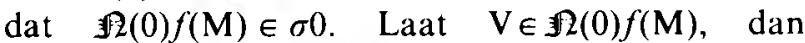
$\mathrm{V} \supset \mathrm{N}_{\mathrm{c}}(0) f(\mathrm{M})=f\left(\mathrm{~N}_{\varepsilon}(0) \mathrm{M}\right)$ vir 'n sekere $\varepsilon>0$. Omdat $\mathrm{N}_{\varepsilon}(0) \mathrm{M} \in \mathfrak{\Omega}(0) \mathfrak{b} \subset \mathfrak{G}$ volg dat $\mathrm{V} \in f(\mathfrak{\beta})$, dus $\mathfrak{R}(0) f(\mathrm{M}) \subset f(\mathbb{G})$. Dus $f(\mathbb{B}) \in \sigma 0$.

HULPSTELLING 2. Gestel $(\mathrm{E}, \tau)$ en $(\mathrm{F}, \sigma)$ is pseudotopologiese vektorruimtes en $f: \mathrm{E} \rightarrow \mathrm{F}$ is 'n $\tau-\sigma-k$ wasibegrensde lineêre afbeelding. Dan

(1) is $f \tau$ - $\sigma$-begrens;

(2) as $(\mathrm{E}, \tau)$ ewewigtig is, is $f \tau-\sigma-k o n t i n u$.

Bewys. (1) Gestel $B$ is 'n $\tau$-begrensde deelversameling van $\mathrm{E}$, dan $\mathfrak{R}(0) \mathfrak{\Omega}(0) \mathrm{B} \in \tau 0$, dus $\mathfrak{\Omega}(0) f(\mathfrak{\Omega}(0) \mathrm{B}) \in \sigma 0$, d.w.s. $12(0) f(\mathrm{~B}) \in \sigma 0$. Dus is $f(\mathrm{~B}) \sigma$-begrens.

(2) Gestel $f^{f} \in \tau 0$. Daar bestaan $f \in t 0$ sodat $\mathfrak{A}(0) \subset \mathfrak{f}$. Omdat $\mathfrak{Z}(0) \mathfrak{B}$ 'n $\tau$-kwasibegrensde filter is volg dat $\mathfrak{Z}_{(0)} f(\mathfrak{\Omega}(0) \mathcal{G}) \in \sigma 0$, dus

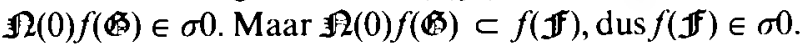

HULPSTELLING 3. Gestel $(\mathrm{E}, \tau)$ en $(\mathrm{F}, \sigma)$ is pseudotopologiese vektorruimtes en $f: \mathrm{E} \rightarrow \mathrm{F}$ is ' $n \tau$ - $\sigma$-begrensde lineêre afbeelding. As (E, $\tau)$ lokaulhegrens is volg dat $f \tau-\sigma-k$ wasibegrens is.

Bewys. Gestel $\mathfrak{f} \in \mathbb{F}(\mathrm{E})$ en $\mathfrak{H}(0) \mathfrak{f} \in \tau 0$. Daar bestaan ' $n \tau$-begrensde versameling $\mathbf{B}$ sodat $\mathbf{B} \in \mathfrak{R}(0) \mathfrak{I}$. Omdat $\mathfrak{B}(0) f(\mathrm{~B}) \subset \mathfrak{R}(0) f(\mathfrak{H})$ en $\mathfrak{R}(0) f(\mathrm{~B}) \in \sigma 0$ volg dat $\mathfrak{B}(0) f(\mathfrak{H}) \in \sigma 0$.

STELLING 1. Gestel (E, $\tau$ ) is 'n pseudotopologiese vektorruimte. Dan is die volgende ekwivalent.

(1) (E, $\tau$ ) is bornologies.

(2) $(\mathrm{E}, \tau)$ is lokaalbegrens en ewewigtig.

(3) Elke $\tau$ - $\sigma$-begrensde lineêre afbeelding van $\mathrm{E}$ in $\mathrm{F}$, waar $(\mathrm{F}, \sigma)$ enige pseudotopologiese vek torruimte is, is $\tau-\sigma$-kontinu.
(4) (E, $\tau)$ is lokaalbegrens en elke $\tau-\sigma-k w a s i b e g r e n s d e$, lineêre afbeelding van $\mathrm{E}$ in $\mathrm{F}$, waar $(\mathrm{F}, \sigma)$ enige pseu-

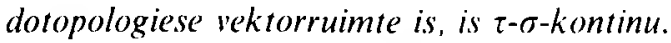

(5) As (F, $\sigma$ ) enige pseudotopologiese vektorruimte is en $\mathrm{H}$ is ' $n$ versameling van lineêre afbeeldings van $\mathrm{E}$ in $\mathrm{F}$ sodat vir elke $\tau$-hegrensde versameling $\mathrm{B}$ die versameling $\mathrm{H}(\mathrm{B}) \sigma$-hegrens is, dan $[\mathrm{H}](\mathfrak{f}) \in \sigma 0$ vir clke $\mathfrak{y} \in \tau 0$.

Bewls. Die implikasie (5) $\Rightarrow(3)$ is triviaal, (1) $\Rightarrow(2)$ en $(1) \Leftrightarrow(3)$ is deur De Bruyn ${ }^{2}$ bewys. Die implikasies (2) $\Rightarrow(3),(3) \Rightarrow$ (4) en (4) $\Rightarrow$ (3) volg onderskeidelik van hulpstelling $\mathrm{I},(2)$ en hulpstelling $2(1)$ en (3). Ons bewys $(1) \Rightarrow(5)$. Gestel $(E, \tau)$ is bornologies. As $\mathbb{f} \in \tau 0$ bestaan 'n $\tau$-begrensde versameling $B$ sodat $\mathfrak{2}(0) \mathrm{B} \subset \mathfrak{f}$. Laat $(\mathrm{F}, \sigma)$ 'n pseudotopologiese vektorruimte wees en laat $H$ 'n versameling lineêre afbeeldings van $E$ in $F$ wees wat aan die aanname in (5) voldoen. As $\varepsilon>0$ volg dat $\mathrm{N}_{\varepsilon}(0) \mathrm{H}(\mathrm{B})=\mathrm{H}\left(\mathrm{N}_{\varepsilon}(0) \mathrm{B}\right)$, dus $\mathfrak{N}(0) \mathrm{H}(\mathrm{B}) \subset[\mathrm{H}](\mathfrak{J})$. Dus $[\mathrm{H}](\mathfrak{I}) \in \sigma 0$.

As $X$ ' $n$ versameling is word 'n nie-leë klas van deelversamelings van $X$ ' $n$ duale filter in $X$ genoem as $\{X \backslash D$ : $D \in \mathbb{Z}\}$ ' $n$ filter in $X$ is. Die volgende karakterisering van bornologiese pseudotopologiese vektorruimtes volg van stelling 1 en $5.19 .3 .^{4}$

STELLING 2. Gestel (E, $\tau$ ) is in bornologiese pseudotopologiese vektorruimte. Dan bestaan daar 'n duale filter $\mathbb{Z} \neq\{0\}$ in E sodat

(1) as $\mathrm{A} \in \mathbb{D}$ en $\mathrm{B} \in \mathbb{D}$, dan $\mathrm{A}+\mathrm{B} \in \mathbb{\mathbb { B }}$,

(2) as $\mathrm{N} \in \mathfrak{\Re ( 0 )}$ en $\mathrm{A} \in \mathbb{Z}$, dan $\mathrm{NA} \in \mathbb{Z}$, en

(3) as $x \in \mathrm{E}$, dan $\{x\} \in \mathbb{D}$,

en waarvoor $\tau 0=\{\mathfrak{f} \in \mathbb{F}(E)$ : $\mathfrak{f} \supset \mathfrak{B}(0) \mathrm{D}$ vir 'n sekere $\mathrm{D} \in \mathbb{Z}\}$. Omgekeerd, as $E$ 'n vektorruinte is en 现 $\neq\{\emptyset\}$ is ' $n$ duale filter in $E$ wat (1), (2) en (3) bevredig, en as $\tau 0$ soos hierbo gedefinieer word en $\tau x=\{x+\mathbb{1}: \mathbb{f} \in \tau 0\}$ vir elke $x \in \mathrm{E}$, dan is $(\mathrm{E}, \tau)$ 'n bornologiese pseudotopologiese verktorruimte. Verder is $(\mathrm{E}, \tau)$ Hausdorff' as en slegs as vir elke nieleё gebalanseerde versameling $\mathrm{D} \in \mathbb{\mathrm { I }}$ volg dat $\cap\{\lambda \mathrm{D}: \lambda>0\}=\{0\}$.

GEVOLGTREKKING. Gestel (E, $\tau)$ is 'n hornologiese lokaalkonvekse pseudotopologiese vektorruimte. Dan

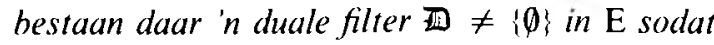

(1) as $\mathrm{D} \in \mathbb{\boxplus}$, dan is die absoluutkonvekse omhulsel van $\mathrm{D}$ 'n element van $\mathrm{D}$, en

(2) as $x \in \mathrm{E}$, dan $\{x\} \in \mathbb{Z}$,

en waarvoor $\tau 0=\{\mathbb{f} \in \mathbb{F}(E): \mathbb{J} \supset \mathfrak{\Omega}(0) \mathrm{D}$ vir'n sekere $\mathrm{D} \in \mathrm{X}$ \}! Omgekeerd, as $\mathrm{E}$ 'n vektorruimte is en $\varpi \neq\{\emptyset\}$ is 'n duale filter in $\mathrm{E}$ wat (1) en (2) bevredig, as $\tau 0$ soos hierbo gedefinieer word en $\tau x=\{x+\mathfrak{y}$ : $\mathfrak{f} \in \tau 0\}$ vir elke $x \in \mathrm{E}$, dan is $(\mathrm{E}, \tau)$ in hornologiese lokaalkonvekse pseudotopologiese vektorruimte.

Daar bestaan Hausdorff bornologiese lokaalkonvekse pseudotopologiese vektorruimtes wat nie topologiese vektorruimtes is nie (kyk 5.194). 


\section{BASIESE EIENSKAPPE EN KONSTRUKSIES}

PROPOSISIE I. Gestel (E, $\tau$ ) is 'n hornologiese pseudotopologiese vektorruimte. As $\mathrm{U} \subset \mathrm{E}$ alle $\tau$-hegrensde versamelings absorbeer dan volg $\mathrm{U} \in \cap\{\mathfrak{J F}: \mathfrak{j f} \in \tau 0\}$.

Bewls. Gestel $\mathbb{I} \in \tau 0$. Daar bestaan 'n $\tau$-begrensde versameling $B$ sodat $\geqq(0) B \subset \mathbb{y}$. Omdat $U$ vir $B$ absorbeer bestaan $\varepsilon>0$ sodat $\lambda \mathrm{B} \subset \mathrm{U}$ vir alle $\lambda$ waar $|\lambda|<\varepsilon$. Dus $\mathrm{N}_{\mathrm{\varepsilon}}(0) \mathrm{B} \subset \mathrm{U}$, d.w.s. $\mathrm{U} \in \mathfrak{\Omega}(0) \mathrm{B} \subset \mathfrak{f F}$. Dus $U \in \cap\{\mathfrak{f}: \mathbb{f} \in \tau 0\}$.

PROPOSISIE 2. Gestel (E, $\tau$ ) is 'n pseudotopologiese vektorruimte met die eienskap dat as $\mathrm{U} \subset \mathrm{E}$ elke $\tau$-hegrensde versameling absorheer, dan $\mathrm{U} \in \cap\{\mathbb{f}: \mathfrak{I} \in \tau 0\}$. As $(\mathrm{F}, \sigma)$ 'n pseudotopologiese vektorruimte en $f: \mathrm{E} \rightarrow \mathrm{F}$ 'n $\tau$ - $\sigma$-begrensde lineêre afheelding is, dan volg dat f $\tau-\sigma-b y$ na oral kominu is.

Bewys. Gestel $\mathrm{V} \in \cap\{\sigma: \sigma \in \sigma 0\}$ en laat $\mathrm{B}$ 'n $\tau$-begrensde versameling wees. Omdat $f(\mathrm{~B}) \sigma$-begrens is volg dat $\mathrm{V} \in \mathfrak{R}(0) f(\mathrm{~B})$ en daar bestaan $\varepsilon>0$ sodat $\mathrm{N}_{\varepsilon}(0) f(\mathrm{~B}) \subset \mathrm{V}$, d.w.s. $\lambda \mathrm{B} \subset f^{\prime}(\mathrm{V})$ vir alle $\lambda$ waar $|\lambda|<\varepsilon$. Dus $f^{\prime}(\mathrm{V}) \in \cap\{\mathbb{f}: \mathbb{f} \in \tau 0 ;$ en $f$ is $\tau$ - $\sigma$-byna kontinu.

Kontinue afbeeldings tussen pseudotopologiese ruimtes is byna kontinu; die twee begrippe is dieselfde as die beeldruimte ' $n$ topologiese ruimte is (kyk $\left.3.6 \cdot 3^{4}\right)$.

PROPOSISIE 3. Gestel (E, $\tau$ ) is 'n pseudotopologiese vektorruimte met die eienskap dat daar 'n $\tau$-hegrensde versameling $\mathrm{B} \in \cap\left\{\mathfrak{f}: \mathfrak{y}^{\mathrm{f}} \in \tau 0\right.$ \} bestaun. Dan is $(\mathrm{E}, \tau)$ bornologies en absorberend. Vercier is $(\mathrm{E}, \tau)$ dan ' $n$ lokaalhegrensde topologiese vektorraimte.

B'wy's. Gestel $(\mathrm{F}, \sigma)$ is 'n pseudotopologiese vektorruimte en $f: \mathrm{E} \rightarrow \mathrm{F}$ is 'n $\tau$ - $\sigma$-begrensde lineêre afbeelding. Omdat $f(\mathrm{~B}) \sigma$-begrens is, is $f \tau-\sigma$-kontinu (kyk Proposisie 2.2(a) ${ }^{1}$ ). Volgens stelling $1(3)$ is $(E, \tau)$ bornologies. Omdat $B$ absorberend en $\tau$-begrens is, is D2(0)B ' $n$ filter in $\tau 0$ wat uit absorberende versamelings bestaan. Dus is (E, $\tau$ ) absorberend. Ten slotte, gestel $\varepsilon>0$. Dan $\varepsilon B \in \cap\{\mathfrak{f f}: \mathfrak{f f} \in \tau 0\}$ en $\varepsilon B \subset N_{\varepsilon}(0) B$, dus $\left.\mathrm{N}_{\mathrm{c}}(0) \mathrm{B} \in \cap: \mathfrak{I F}: \mathfrak{I} \in \tau 0\right\}$. Dus $\mathfrak{\Omega}(0) \mathrm{B} \subset \cap\{\mathfrak{I}: \mathfrak{y} \in \tau 0\}$. Omdat $\mathrm{B} \tau$-begrens is, volg $\cap\{\mathfrak{f}: \mathbb{f} \in \tau 0\} \in \tau 0$, dus $\tau 0=[\Omega(0) B]$ en $(E, \tau)$ is ' $n$ topologiese vektorruimte waarin $\_(0) B$ die omgewingsfilter van die oorsprong is. Omdat $B$ ' $n$ begrensde omgewing van die oorsprong in hierdie topologie is, is $(E, \tau)$ 'n lokaalbegrensde topologiese vektorruimte.

GEVOLGTREKKING. Gestel $(\mathrm{E}, \tau)$ is 'n Hausdorff lokaalhegrensde pseudotopologiese vektorruimte. As daar 'n $\tau$-prekompakte versameling $\mathrm{M} \in \cap\{\mathfrak{I}: \mathfrak{I} \in \tau 0\}$ bestaan, dan is $\mathrm{E}$ eindig-dimensionaal.

Bewys. Volgens stelling $2.1^{2}$ is $\mathrm{M} \tau$-begrens. Die bewering volg van proposisie 3 en die feit dat $M$ 'n prekompakte omgewing van die oorsprong in die Hausdorfftopologie op E is.
Daar bestaan absorberende bornologiese pseudotopologiese vektorruimtes wat nie topologiese vektorruimtes is nie (kyk 5.194).

VOORBEELD. Die reële pseudotopologiese vektorruimte $(R, \tau)$ met $\tau 0=\{\mathbb{f} \in \mathbf{F}(\mathbf{R}):[-\lambda, \lambda] \in \mathbb{f}$ vir'n sekere $\lambda>0$ is lokaalbegrens maar nie bornologies nie. ${ }^{2}$ Vir elke $\varepsilon>0$ is die filter wat deur $[-\varepsilon, \varepsilon]$ voortgebring word ' $n$ absorberende filter in $\tau 0$, dus is $(R, \tau)$ absorberend.

PROPOSISIE 4. Gestel (E, $\tau$ ) is 'n hornologiese pseudotopologiese vektorruimte. Dan is elke $\tau-\tau_{\mathrm{R}}$-hegrensde seminorm op $\mathrm{E} \tau-\tau_{\mathrm{R}}-k o n t i n u$.

Bewys. Gestel $x \in \mathrm{E}$ en $\mathfrak{y} \in \tau x$. Daar bestaan $\in \tau 0$ sodat $\mathfrak{f}=x+($ D. Daar bestaan 'n $\tau$-begrensde deelversameling $B$ van $E$ sodat $\mathfrak{R}(0) B \subset \mathbb{B}$. Laat $\boldsymbol{\varepsilon}>0$ en gestel $p$ is 'n $\tau-\tau_{\mathrm{R}}$-begrensde seminorm op E. Dan $p(x)+\mathrm{N}_{\varepsilon}(0) p(\mathrm{~B}) \supset p(x)+[0, \varepsilon] p(\mathrm{~B}) \supset p\left(x+\mathrm{N}_{\mathrm{c}}(0) \mathrm{B}\right)$, dus $\quad p(\mathbb{f}) \supset p(x+\mathfrak{\Omega}(0) \mathrm{B}) \supset p(x)+\mathfrak{\Omega}(0) p(\mathrm{~B})$. Omdat $p(\mathrm{~B}) \tau_{\mathrm{R}}$-begrens is, volg $p(\mathfrak{y}) \in \tau_{\mathrm{R}} p(x)$.

Vervolgens ondersoek ons eienskappe van bornologiese pseudotopologiese vektorruimtes wat op ander vektorruimtes oorgedra word. Gestel $(E, \tau)$ is 'n pseudotopologiese vektorruimte, $M$ is 'n vektordeelruimte van $\mathrm{E}$ en $f$ is die kanoniese afbeelding van $\mathrm{E}$ op $\mathrm{E} / \mathrm{M}$. Die kwosiënt pseudotopologiese vektorruimtestruktuur $\sigma$ op $\mathrm{E} / \mathrm{M}$ word gedefinieer as daardie waarvoor die versameling van alle filters $f(\mathbb{f})$ (waar $\mathbb{f} \in \tau x$ vir' sekere $x \in \mathrm{M})$ 'n subbasis van $\sigma 0$ is $\left(\mathrm{kyk} 5.15 \mathrm{c}^{4}\right)$.

PROPOSISIE 5. Gestel (E, $\tau$ ) is 'n hornologiese pseudotopologiese vektorruimte en $\mathrm{M}$ is 'n vektordeelruimte $v a n$ E. Dan is $(\mathrm{E} / \mathrm{M}, \sigma)$, waar $\sigma$ die kwosiënt pseudotopologiese vektorruimtestruktuur op $\mathrm{E} / \mathrm{M}$ is, ' $n$ bornologiese pseudotopologiese vektorruimte.

Bewys. Gestel of $\in \sigma 0$ en $f: \mathrm{E} \rightarrow \mathrm{E} / \mathrm{M}$ is die kanoniese afbeelding. Daar bestaan $\mathfrak{f}_{i} \in \tau x_{i}$, waar $x_{i} \in \mathrm{M}$ $(i=1,2, \ldots, n)$, sodat $\cap\left\{f\left(\mathfrak{J}_{i}\right): i=1,2, \ldots, n\right\} \subset \mathbb{B}$. Vir elke $i$ bestaan 'n $\tau$-begrensde deelversameling $\mathrm{B}_{i}$ van $\mathrm{E}$ sodat $\mathfrak{\Omega}(0) \mathrm{B}_{i} \subset \mathfrak{J}_{i}-\boldsymbol{x}_{i}$, dus $f\left(\mathfrak{\Omega}(0) \mathrm{B}_{i}\right) \subset$ $f\left(\mathfrak{H}_{i}-x_{i}\right)=f\left(\mathfrak{H}_{i}\right)$. Laat $\mathrm{A}=\cup\left\{f\left(\mathrm{~B}_{i}\right): i=1,2, \ldots\right.$, $n\}$. Vir elke $\varepsilon>0$ volg dat $\mathrm{N}_{\varepsilon}(0) \mathrm{A}=\cup\left\{f\left(\mathrm{~N}_{\mathrm{v}}(0) \mathrm{B}_{t}\right)\right.$ : $i=1,2, \ldots, n\} \in \cap\left\{f\left(\mathbb{F}_{i}\right): i=1,2, \ldots, n\right\}$, dus 12(0)A $\subset$. Omdat $f \tau$ - $\sigma$-kontinu is, is $\mathrm{A}$ 'n $\sigma$-begrensde deelversameling van $\mathrm{E} / \mathrm{M}$. Dus is $(\mathrm{E} / \mathrm{M}, \sigma)$ bornologies.

Gestel $I$ is ' $n$ nie-leë indeksversameling en vir elke $\alpha \in \mathrm{I}$ is $\left(\mathrm{E}_{\alpha}, \tau_{\alpha}\right)$ 'n pseudotopologiese vektorruimte oor $\Phi$. Gestel $\mathrm{E}$ is die direkte som van die klas $\left(\mathrm{E}_{\alpha}\right)_{z \in 1}$ en vir elke $\alpha \in \mathrm{I}$ is $f_{x}: \mathrm{E}_{x} \rightarrow \mathrm{E}$ die kanoniese afbeelding. Die direkte som pseudotopologiese vektorruimtestruktuur $\sigma$ op E word gedefinieer as daardie waarvoor die versameling van alle eindige somme van die tipe $f_{\alpha(1)}\left(\mathfrak{J}_{1}\right)+\ldots+f_{x(n)}\left(\mathfrak{J}_{n}\right)$ (waar $n$ 'n natuurlike getal is, $\mathfrak{y}_{i} \in \tau_{x(i)} x_{i}$ vir $i=1,2, \ldots, n$ en $f_{\alpha(1)}\left(x_{1}\right)+\ldots+$ 
$f_{x(n)}\left(x_{n}\right)=0$ ) 'n subbasis van $\sigma 0$ is $\left(\mathrm{kyk} 5.15 \mathrm{~d}^{4}\right)$. Dit volg dat elke $f_{\alpha} \tau_{x}-\sigma$-kontinu is.

PROPOSISIE 6. Gestel I is 'n nie-leë indeksversameling. Vir elke $\alpha \in \mathrm{I}$ laat $\left(\mathrm{E}_{\alpha}, \tau_{x}\right)$ 'n bornologiese pseudotopologiese vektorruimte oor $\Phi$ wees. As $\mathrm{E}$ die direkte som van die klas $\left(\mathrm{E}_{\alpha}\right)_{x \in 1}$ is en $\sigma$ is die direkte som pseudotopologiese vektorruimtestruktuur op $\mathrm{E}$, dan is $(\mathrm{E}, \sigma)$ 'n bornologiese pseudotopologiese vektorruimte.

Die bewys is soortgelyk aan dié van proposisie 5 .

STELLING 3. Gestel (E, $\tau)$ is 'n bornologiese lokaalkonvekse pseudotopologiese vektorruimte. Daar bestaan in klas $\left(\left(\mathrm{E}_{\alpha}, \tau_{x}\right)\right)_{\alpha \in 1}$ van lokaalkonvekse topologiese vektorruimtes (waar vir elke $\alpha \in I \tau_{x}$ die geassosieerde lokaalkonvekse pseudotopologiese vektorruimtestruktuur op $\mathrm{E}_{\alpha}$ is) en vir elke $\alpha \in \mathrm{I}$ bestaan in lineêre afbeelding $f_{x}: \mathrm{E}_{x} \rightarrow \mathrm{E}$ sodat $\tau$ die finste pseudotopologiese vektorruimtestruktuur op $\mathrm{E}$ is waarvoor elke $f_{x} \tau_{x}-\tau-k o n-$ tinu is. Ook $\mathrm{E}=\cup\left\{f_{\alpha}\left(\mathrm{E}_{\mathrm{x}}\right): \alpha \in \mathrm{I}\right\}$. Verder. as $(\mathrm{E}, \tau)$ Hausdorff is, is elke $\mathrm{E}_{\alpha}$ 'n genormeerde ruimte.

Bew'ys. Gestel B is 'n nie-leë absoluutkonvekse $\tau$-begrensde deelversameling van $E$. Laat $E_{B}=\operatorname{span} B$ en gestel $f_{\mathrm{B}}: \mathrm{E}_{\mathrm{B}} \rightarrow \mathrm{E}$ is die gebruiklike injektiewe afbeelding. Die Minkowski-funksionaal $p_{\mathrm{B}}$ van $\mathrm{B}$ is 'n seminorm op $E_{B}$. Onder hierdie seminorm is $E_{B}$.n lokaalkonvekse topologiese vektorruimte. Gestel $\mathfrak{a}_{\mathrm{B}}$ is die omgewingsfilter van die oorsprong in $\mathrm{E}_{\mathrm{B}}$ met betrekking tot die lokaalkonvekse topologie. Gestel $\tau_{\mathrm{B}}$, waar $\tau_{B} 0=\left[\mathfrak{A}_{B}\right]$, is die geassosieerde pseudotopologiese vektorruimtestruktuur op $E_{B}$. Gestel $\tau^{\prime}$ is die fynste pseudotopologiese vektorruimtestruktuur op E waarvoor elke $f_{\mathrm{B}} \tau_{\mathrm{B}}-\tau^{\prime}$-kontinu is. Ons toon aan dat $\tau^{\prime} 0=\tau 0$. Laat $\mathfrak{H} \in \tau_{\mathrm{B}} 0$, dan $f_{\mathrm{B}}(\mathfrak{f}) \supset f_{\mathrm{B}}\left(\mathfrak{U}_{\mathrm{B}}\right)$. As $\varepsilon>0$ dan volg dat $\mathrm{N}_{\varepsilon}(0) \mathrm{B} \supset\left\{. x \in \mathrm{E}_{\mathrm{B}}: p_{\mathrm{B}}(x)<\varepsilon / 2\right\}$, dus $f_{\mathrm{B}}\left(\mathfrak{d}_{\mathrm{B}}\right) \supset \mathfrak{\Omega}(0) \mathrm{B}$. Omdat $\mathrm{B} \tau$-begrens is, volg $f_{\mathrm{B}}(\mathfrak{f}) \in \tau 0$, d.w.s. $f_{\mathrm{B}}$ is $\tau_{\mathrm{B}}-\tau$-kontinu. Omdat $\tau^{\prime}$ die fynste pseudotopologiese vektorruimtestruktuur met hierdie eienskap is, volg $\tau^{\prime} 0 \subset \tau 0$. Omgekeerd, laat
$\mathcal{H} \in \tau 0$. Daar bestaan 'n $\tau$-begrensde deelversameling $A$ van $E$ sodat $\mathfrak{f} \supset \mathbb{1 2 ( 0 ) A}$. Die absoluutkonvekse

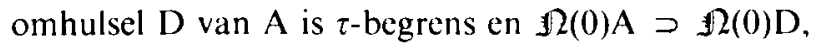
dus $\mathfrak{y} \supset \mathfrak{M}(0) \mathrm{D}$. As $\varepsilon>0$ volg dat $\left\{x \in \mathrm{E}_{1}: p_{1}(x)<\varepsilon\right.$; $\supset N_{\varepsilon / 2}(0) D$. Laat $(\mathfrak{2}(0) D)_{1}$, die filter $\mathfrak{2}(0) \mathrm{D}$ in $E_{1}$ aandui, dan $\mathfrak{G}_{\mathrm{D}} \subset(\boldsymbol{N}(0) \mathrm{D})_{1}$, d.w.s. $(\mathfrak{\Omega}(0) \mathrm{D})_{1)} \in \tau_{1} 0$. Omdat $f_{\mathrm{D}} \tau_{\mathrm{D}}-\tau^{\prime}$-kontinu is en $\Omega(0) \mathrm{D}=f_{\mathrm{D}}\left((\Omega(0) \mathrm{D})_{\mathrm{D}}\right)$, $\operatorname{volg} \Re(0) D \in \tau^{\prime} 0$. Dus $\mathfrak{J} \in \tau^{\prime} 0$ en gevolglik $\tau 0 \subset \tau^{\prime} 0$. Gestel $(E, \tau)$ is ook Hausdorff. Gestel $B$ is soos hierbo en $x$ is ' $n$ nie-nul element van $\mathrm{E}_{\mathrm{p}}$. Dan $\tau x \cap \tau 0=\emptyset$. Gestel $p_{\mathrm{B}}(x)=0$, dan $x \in \lambda \mathrm{B}$ vir alle $i>0$, d.w.s. $x \in \mathrm{N}_{v}(0) \mathrm{B}$ vir alle $\varepsilon>0$. Dus $\mathfrak{2}(0) \mathrm{B} \subset[x]$ en $[x] \in \tau x \cap \tau 0$, 'n teenst rydigheid. Derhalwe $p_{\mathrm{B}}(x)>0$ en is $p_{\mathrm{B}}$ 'n norm op $\mathrm{E}_{\mathrm{B}}$.

VOORBEELD. Gestel $\mathrm{E}$ is 'n vektorruimte met basis $\left\{y_{x}: x \in I\right\}$. 'n Pseudotopologiese vektorruimtestruktuur $\tau$ op $\mathrm{E}$ word gedefinieer as daardie waarvoor $\tau 0=\left\{\mathfrak{f} \in \mathbf{F}(\mathrm{E}): \mathfrak{f} \supset \mathfrak{Q}(0) \boldsymbol{x}_{1}+\ldots+\mathfrak{Q}(0) x_{n}\right.$ vir' $n$ sekere eindige deelversameling $\left\{x_{1}, \ldots, x_{n}\right\}$ van $\left.\mathrm{E}\right\}$. Volgens stelling 1 en $5.10 .4^{4}$ en $5.19 .16^{4}$ is (E, $\tau$ ) 'n bornologiese lokaalkonvekse pseudotopologiese vektorruimte. As $J$ 'n nie-leë eindige deelversameling van $I$ is, laat $\mathrm{E}_{\mathrm{J}}=\operatorname{span}\left\{y_{x}: x \in \mathrm{J}\right\}$. Laat $\tau_{\mathrm{J}}$ die pseudotopologiese vektorruimtestruktuur op $E_{\jmath}$ wees wat met die natuurlike topologie op $E_{J}$ geassosieer is. Volgens Gähler 5.19.16 is $(E, \tau)$ die induktiewe limiet in die kategorie van pseudotopologiese vektorruimtes van die klas $\left(\left(E_{\jmath}, \tau_{\mathrm{J}}\right)\right.$ : $\mathrm{J}$ is 'n nie-leë eindige deelversameling $\operatorname{van}$ I).

Die outeur is dankbaar vir finansiële ondersteuning deur die WNNR en die Universiteit van Stellenbosch.

\section{VERWYSINGS}

1. De Bruyn, G. F. C. (1975). Concepts in vector spaces with convergence structures, Canadian Math. Bull. 18, 499-502.

2. De Bruyn, G. F. C. (1984). On vector spaces with locally bounded convergence structures, Quaestiones Math. 7, 377-383.

3. Fischer, H. R. (1959). Limesräume. Math. Ann. 137. 269-303.

4. Gähler, W. (1977/78). Grundstrukturen der Analvsis (Birkhäuser Verlag. Basel - Stuttgart)

5. Hogbe-Nlend, H. (1971). Theoric des bornologies et applications, Lecrure Notes in Math. 213 (Springer-Verlag). 